\title{
The Role of Wastewater Treatment Plants in the Environmental Dissemination of Antibiotic Resistant Bacteria (ARB) and Resistance Genes (ARG)
}

\author{
Abidelfatah M. Nasser', Heitam Fawaqa',2, Yeshayahu Nitzan ${ }^{2}$ \\ ${ }^{1}$ Water Quality Research Laboratory, National Public Health Laboratory, Ministry of Health, Tel Aviv, Israel \\ ${ }^{2}$ Faculty of Life Sciences, Bar-Illan University, Ramat Gan, Israel \\ Email: abid.nasser@phlta.health.gov.il
}

How to cite this paper: Nasser, A.M., Fawaqa, H. and Nitzan, Y. (2019) The Role of Wastewater Treatment Plants in the Environmental Dissemination of Antibiotic Resistant Bacteria (ARB) and Resistance Genes (ARG). Journal of Water Resource and Protection, 11, 981-994.

https://doi.org/10.4236/jwarp.2019.118058

Received: July 1, 2019

Accepted: August 12, 2019

Published: August 15, 2019

Copyright $\odot 2019$ by author(s) and Scientific Research Publishing Inc. This work is licensed under the Creative Commons Attribution International License (CC BY 4.0).

http://creativecommons.org/licenses/by/4.0/

(c) $\underset{\mathrm{EY}}{\mathrm{B}}$ Open Access

\begin{abstract}
This study was conducted to evaluate the influence of wastewater treatment processes on the prevalence of antibiotic resistance fecal coliform (FC) and antibiotic resistance genes (ARGs) of FC. In addition, the occurrence of antibiotic resistant bacteria (ARB) and antibiotic resistant genes (ARGs) in surface waters receiving wastewater was evaluated. Greater resistance against penicillin (P), colisitin (CT) and ampicillin (AMP) were observed for FC isolated from effluent disinfected by chlorine (71\%), than that disinfected by UV (45\%). The greatest resistance against six antibiotics was recorded for FC isolates from effluent disinfected by chlorine. The prevalence of tetB and bla $\mathrm{SHV}_{\mathrm{SH}}$ was lowest in isolates from chlorine-disinfected effluents. The occurrence of ARG bla $\mathrm{SHV}_{\mathrm{SH}}$ was highest in FC isolated from effluent disinfected by UV. A significant correlation was recorded between FC levels in surface waters and the level of bacterial resistance to ampicillin $(\mathrm{P}<0.05)$ and to chloramphenicol $(\mathrm{P}<0.05)$. AmpC and blaPSE1 were more prevalent than $\mathrm{bla}_{\mathrm{SHV}}$ in effluents and in surface waters. TetA and tetC were highly prevalent in surface water compared to tetB. The results of the study demonstrate the widespread prevalence of $A R B$ and ARG in wastewater and receiving water bodies. The result indicates that the source of $A R B$ and $A R G$ in surface waters originate from wastewater. Released ARB and ARG may serve as the source of ARG to pathogenic bacteria in surface waters. Disinfection processes may influence the selection of antibiotic resistant patterns of bacteria.
\end{abstract}

\section{Keywords}

Wastewater, Antibiotic Resistant Bacteria, Genes, Treatment, Disinfection 


\section{Introduction}

The widespread application of antibiotics in human and veterinary medicine has led to the emergence, selection, and dissemination of antibiotic resistant bacteria (ARB) and antibiotic resistance genes (ARGs) in different environmental compartments throughout the world. Currently, there is a lack of knowledge with respect to the origin of ARB and ARGs in different surface waters (e.g. stream water and bathing water) and their removal by advanced wastewater treatment processes.

Antibiotic resistance gained increased attention in the past years-not least due to alarming reports of the World Health Organization (WHO). Studies demonstrated the presence of antibiotic resistant bacteria in clinical, domestic and industrial wastewaters [1] [2] [3]. The resistant bacteria reach wastewater treatment plants, where currently insufficient microbial reduction is accomplished. Therefore, antibiotic resistant bacteria (ARB) and antibiotic resistance genes (ARGs) were found in surface water, groundwater, drinking water and sediments in various regions of the world [4] [5] [6] [7]. The dissemination of $A R B$ and ARGs is facilitated by the horizontal gene transfer enabling the exchange of ARGs among different strains or bacterial species [8] and beyond the habitat of the original host [9]. Wastewater treatment plants (WWTPs), especially activated sludge, provide an opportunity for mobile genetic elements (including ARG) to mix between pathogens, opportunistic pathogens, and environmental bacteria [10]. The effect of clinically relevant ARGs and ARB, that are released, from anthropogenic sources, together with the excessive use of antibiotics in both human and veterinary medicine, is currently considered a serious public health issue. It is assumed that the global spread of ARGs and ARB and the acquisition of the resistance genes by pathogenic bacteria are associated with the increased hospitalization and mortality rates of patients that are infected with such organisms [11]. The treatment of infectious diseases becomes more difficult and the number of deaths associated with antibiotic resistant bacteria increases worldwide. Antibiotic resistance is commonly associated with extra-chromosomal elements, which include different types of mobile DNA segments such as plasmids, transposons and integrons. The introduction of mobile DNA elements is accomplished through the processes of transduction, conjugation and transformation. It is important to note that gene transfer can occur in the same species and in genetically distant species such as gram-positive and gram-negative bacteria. Among the mechanisms, which were developed by bacteria for multidrug resistance (MDR) are: penicillin-binding proteins (PBPs), enzymatic mechanisms of drug modification, mutated drug targets, enhanced efflux pump expression and altered membrane permeability [12]. This study was performed to evaluate the influence of wastewater treatment processes on the prevalence of antibiotic resistance fecal coliform (FC) and antibiotic resistance genes of FC. Furthermore, the influence of wastewater treated effluents on the dissemination of ARB and ARG in receiving surface waters was evaluated. The 
Yarkon Stream was selected for this study because it receives treated wastewater effluents and it flows into the Mediterranean Sea, as a result the ARB and ARG carried by the stream may be the source of ARG to pathogenic bacteria in the marine environment.

\section{Materials and Methods}

\subsection{Samples Collection}

Samples of secondary and tertiary wastewater effluents (disinfected by either chlorine or UV) were collected from two wastewater treatment plants located in the central part of Israel. The treatment train consists of primary settling, activated sludge and tertiary treatment (filtration and disinfection by either chlorine or UV irradiation). One-liter grab samples were collected, held at $4^{\circ} \mathrm{C}$ during transportation to the laboratory and assayed within $2 \mathrm{hrs}$, for the prevalence of AR FC and ARG of FC. To determine the influence of wastewater effluent discharged into surface water on the transmission of ARB and ARG, the following samples were analyzed: 1) secondary, 2) tertiary effluents disinfected by UV, 3) irrigation reservoir receiving tertiary effluents, 4) Yarkon stream, 5) Yarkon outfall into the Mediterranean Sea, and 6) low impact environment (Mediterranean Sea). Forty two samples were collected and transferred to the laboratory. The same samples were used for either ARB or ARG analysis.

\subsection{Fecal Coliform Isolation}

Detection and enumeration of fecal coliform was performed following the procedure of Standard Methods [13]. Enumeration of FC in samples of tertiary effluent, irrigation reservoir and low impact seawater was accomplished by the membrane filtration. On the other hand, samples of secondary effluent, stream water and stream outfall were diluted for the isolation of fecal coliform.

\subsection{Antibiotic Resistance of Fecal Coliform Isolates}

The antimicrobial susceptibility of fecal coliform isolates was determined by the disc-diffusion method (Oxoid, Ballerup, Denmark). Disks containing the following antimicrobial agents were used as representatives of important antibiotic classes: Ampicillin (AMP, $10 \mu \mathrm{g}$ ), Chloramphenicol (C, $30 \mu \mathrm{g})$, Gentamicin (CN, $10 \mu \mathrm{g})$, Cephalotin (KF, $5 \mu \mathrm{g})$, Kanamycin $(30 \mu \mathrm{g})$, Nitrofurantoin (F, $300 \mathrm{mg}$ ), Amoxicillin (AMC, $30 \mu \mathrm{g}$ ), Ciprofloxacin (CIP, $5 \mu \mathrm{g}$ ), Colisitin (CT, $25 \mu \mathrm{g}$ ), Penicillin (10 unit), Streptomycin (S, $10 \mu \mathrm{g}$ ) and tetracycline (TE, $25 \mu \mathrm{g})$. Fecal coliform isolates were inoculated onto Mueller-Hinton agar (Merck) plates. The various antibiotic disks were placed on the inoculated Mueller-Hinton agar plates. After overnight incubation at $37^{\circ} \mathrm{C}$, inhibition zones around each disk were measured to the nearest millimeter. The results were analyzed using the criteria of the Clinical and Laboratory Standards Institute (CLSI, formerly the National Committee for Clinical Laboratory Standards or NCCLS) [14]. The standard strain Escherichia coli K12 was used for quality control [15]. 


\subsection{Enumeration of Antibiotic Resistant Heterotrophic Bacteria}

Antibiotic resistant heterotrophic bacteria in effluents and surface water samples were determined by heterotrophic plate count (HPC). Samples from secondary effluents and stream outfall were diluted, while samples of tertiary effluents, reservoir, stream and seawater were filtered through a $0.22 \mu \mathrm{M}$-pore membrane (Millipore, Billerica, MA) and then placed on Mueller Hinton agar containing the following antibiotics, tetracycline $(20 \mathrm{ug} / \mathrm{ml})$, ampicillin $(60 \mathrm{ug} / \mathrm{ml})$ or chloramphenicol $(10 \mathrm{ug} / \mathrm{ml})$. Plates were incubated along with the negative and positive controls at $37^{\circ} \mathrm{C}$ for $24 \mathrm{~h}$.

\subsection{DNA Extraction}

Genomic DNA was extracted directly from 25 fecal coliform colonies isolated from secondary or tertiary effluents disinfected by either chlorine or UV. DNA of these multidrug resistant isolates was extracted using QIAamp DNA Blood Mini Kit (Qiagen, Germany) according to manufactures instructions. Extracted nucleic acid was stored at $-20^{\circ} \mathrm{C}$ prior to analysis.

To detect ARG from wastewater effluents and surface water samples, DNA was extracted from $50 \mathrm{~mL}$ of each sample by filtration onto a sterile $47-\mathrm{mm} 0.22$ $\mu \mathrm{M}$ polycarbonate filter (Millipore). Filters were placed into a Mo Bio PowerSoil (Mo Bio Laboratories Inc., Carlsbad, CA) tube and DNA was extracted from the filters following the manufacturer's protocol. The purity and quantity of the extracted DNA were measured by a Nanodrop ND-1000 UV-visible light spectrophotometer (Nanodrop Technologies, Wilmington, DE). The extracted DNA was stored at $-20^{\circ} \mathrm{C}$ until assay.

\subsection{PCR Detection of ARGs}

Multi drug resistant fecal coliform isolates were divided into three groups secondary effluent $(n=25)$, tertiary effluent disinfected by UV $(n=25)$ and tertiary effluent disinfected by chlorine $(n=25)$. The fecal coliform isolates were screened for the presence of five antibiotic resistance genes. ARGs include $\beta$-lactam resistance genes $\left(\mathrm{ampC}\right.$, bla $\left._{\mathrm{SHV}}\right)$ and tetracycline resistance genes (tet $\mathrm{A}$, tetB). Previously published primer sets were used for the PCR amplification of ARGs [4].

Polymerase Chain Reaction (PCR) was used for the detection of beta lactams (ampC, bla $\mathrm{SHV}_{\mathrm{SH}}$, blapse1), tetracycline (tetA, tetB, tetC) and chloramphenicol (CAT and Flor) genes in total DNA extracted from secondary effluent, tertiary effluent, reservoir, stream, stream outfall and seawater (low impact) samples (n = 42). PCR was performed with (SimpliAmp Applied Biosystems, USA). A total 42 samples obtained from the six sampling sites (7 samples each) along with control DNA extracted from E. coli (ATCC 25922), previously, published primers were used for the PCR amplification of ARGs [4]. The PCR conditions for ARGs amplification were similar to those reported by Stoll et al. (2012) [4]. Ten microliters of amplified product including positive and negative controls (sterile 
water) were electrophoresed on a $0.5 \%$ agarose gel containing GelRed stain. 100 bp DNA ladder (Biolabs, New England) was used as a standard DNA ladder.

\subsection{Statistical Analysis}

The chi-squared test was used to compare the prevalence of antibiotic resistance phenotypes and sampling site (include wastewater treatment process) among the fecal coliform isolates (against 12 antibiotics) and total heterotrophic antibiotic resistant bacteria (against ampicillin, tetracycline and chloramphenicol). Statistical analysis was performed using Microsoft Excel version 2007 for Windows. A $p$-value of $<0.001$ (by use of the Bonferroni correction) or $<0.05$, considered statistically significant. Pearson correlation was conducted to identify the association between the concentrations of fecal coliform (indicator for fecal contamination) and antibiotic resistant HTB against ampicillin, tetracycline and chloramphenicol among the effluent and surface water samples.

\section{Results and Discussion}

\subsection{Occurrence of AR Fecal Coliform in Secondary Effluent and in Tertiary Effluent Disinfected by Chlorine or UV}

Fecal coliform isolated from wastewater effluents were highly resistant (90\% to 100\%) to penicillin and colisitin (Table 1). Higher resistant to ampicillin was recorded for FC isolated from tertiary effluent disinfected by chlorine as compared $76 \%$ of FC isolated from tertiary effluent disinfected by chlorine were found to be resistant to ampicillin, compared to $42 \%$ and $44 \%$ of FC isolated from secondary effluent and tertiary effluent disinfected by UV. Resistance to streptomycin and tetracycline was similar for FC isolated from secondary effluent (16\% and $16 \%)$ and tertiary effluent disinfected by UV ( $29 \%$ and $38 \%)$, whereas lower level of resistance to streptomycin and tetracycline (7\% and $8 \%)$ was recorded for FC isolated from tertiary effluent disinfected by chlorine.

Wastewater treatment may enhance the selection of ARB especially, after exposure to disinfection agents such as chlorine. Although, chlorination of wastewater effluent may reduce the concentration of FC, it may substantially increase the proportions of ARB. This observation was recorded for FC resistant to AMP and AMC isolated from chlorinated effluent. However, similar AR patterns were observed for secondary effluent and UV disinfected effluent, which indicates that UV at the doses used for effluent disinfection does not result in further AR selection.

\subsection{Prevalence of Multi Drug Resistant (MDR) FC in Secondary Effluent and in Tertiary Effluent Disinfected by Chlorine or UV}

Results of the prevalence of MDR fecal coliform in secondary effluent, tertiary effluent disinfected by either chlorine or UV irradiation are presented in Figure 1. A fecal coliform isolate was considered MDR when it showed resistance to 
more than 3 antibiotics. The highest percentage of FC resistant to 3 antibiotics was recorded for P, CT and AMP, where $71 \%$ of the isolates from tertiary effluent disinfected by chlorine were found resistant. In comparison, $43 \%$ and $45 \%$ of FC isolated from secondary effluent and tertiary effluent disinfected by UV were found resistant to the same three antibiotics, respectively.

Table 1. Resistance of fecal coliform isolates from secondary effluent $(n=200)$, from tertiary effluent disinfected by chlorine $(n=150)$ or by UV irradiation to 12 types of antibiotics.

\begin{tabular}{|c|c|c|c|}
\hline \multirow[t]{2}{*}{ Antibiotic } & \multicolumn{3}{|c|}{$\%$ fecal coliform AR in } \\
\hline & $\begin{array}{l}\text { Secondary } \\
\text { Effluent } \\
(\mathrm{n}=200)\end{array}$ & $\begin{array}{l}\text { Tertiary effluent } \\
\text { UV disinfection } \\
\quad(n=150)\end{array}$ & $\begin{array}{l}\text { Tertiary effluent } \\
\text { Chlorine disinfection } \\
\quad(\mathrm{n}=150)\end{array}$ \\
\hline Ampicillin (AMP, $10 \mu \mathrm{g}$ ) & $42^{*}$ & 44 & 76 \\
\hline Chloramphenicol (C, $30 \mu \mathrm{g})$ & 2 & 11.5 & 3 \\
\hline Gentamicin $(\mathrm{CN}, 10 \mu \mathrm{g})$ & 17 & 18 & 12 \\
\hline Cephalotin (KF, $5 \mu \mathrm{g})$ & 70 & 69 & 51 \\
\hline Kanamycin $(\mathrm{K}, 30 \mu \mathrm{g})$ & 6 & 8 & 11 \\
\hline Nitrofurantoin (F, $300 \mathrm{mg}$ ) & 44 & 63 & 44 \\
\hline Amoxicillin (AMC, $30 \mu \mathrm{g}$ ) & 2 & 5 & 32 \\
\hline Ciprofloxacin (CIP, $5 \mu \mathrm{g})$ & 8 & 9 & 5 \\
\hline Colisitin (CT, $25 \mu \mathrm{g})$ & 97 & 98 & 90 \\
\hline Penicillin (P10 unit) & 100 & 99 & 99 \\
\hline Streptomycin $(\mathrm{S}, 10 \mu \mathrm{g})$ & 16 & 16 & 7 \\
\hline Tetracycline (TE, $25 \mu \mathrm{g}$ ) & 29 & 38 & 8 \\
\hline
\end{tabular}

$\%$ fecal coliform AR was calculated as number of resistant colonies divided by total number of isolated colonies.

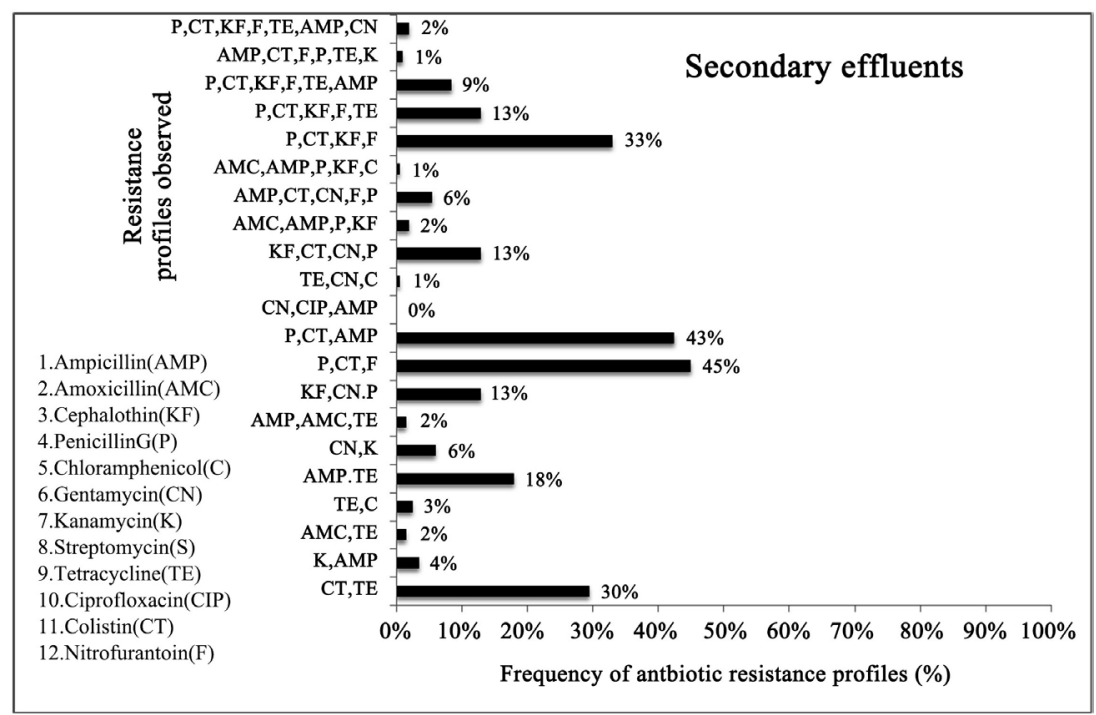

(a) 


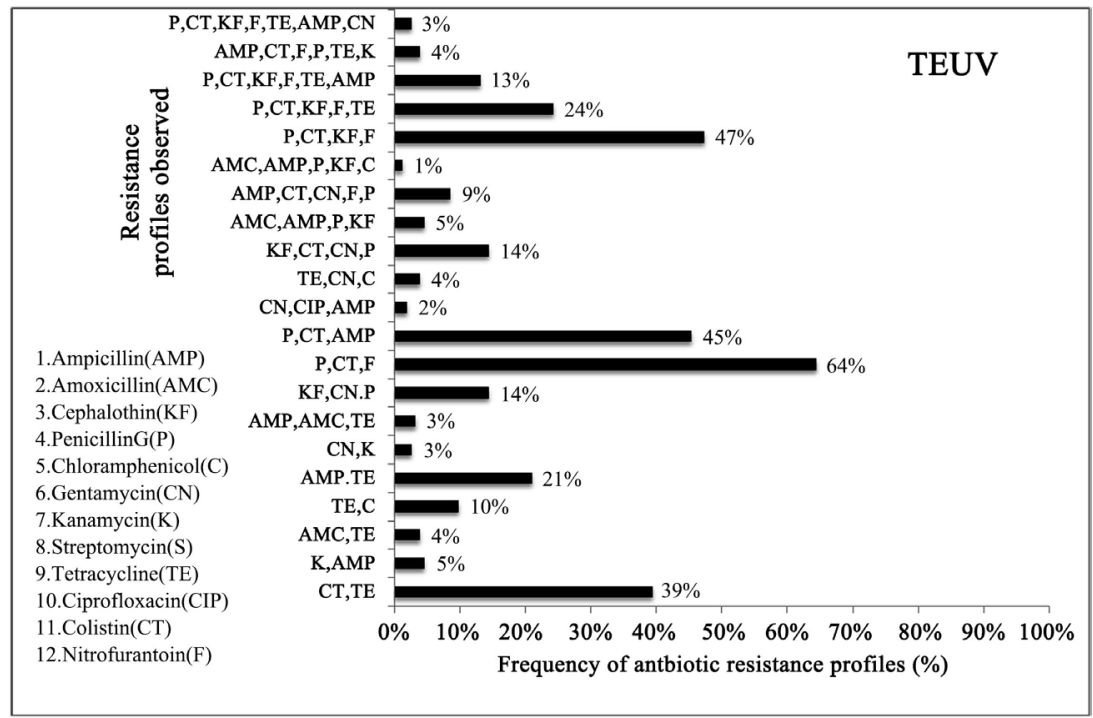

(b)

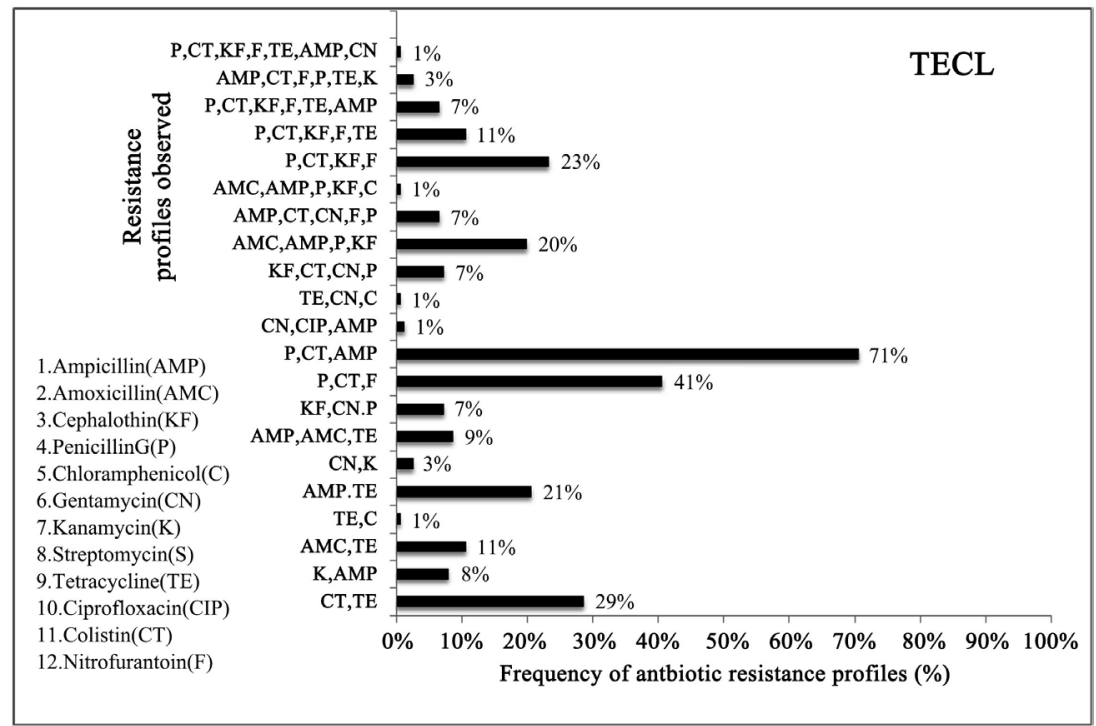

(c)

Figure 1. Profile of Multi drug resistant fecal coliform isolated from: (a) secondary effluent, (b) tertiary effluent disinfected by UV irradiation and (c) tertiary effluent disinfected by free chlorine.

The highest level (47\%) of FC resistant to 4 antibiotics (P, CT, KF and F) was recorded for isolates from tertiary effluent disinfected by UV irradiation. In comparison, lower levels of FC MDR to 4 antibiotics were detected in secondary effluent $(33 \%)$ and tertiary effluent disinfected by UV. The highest difference for MDR resistant to 4 antibiotics (AMC, AMP, $\mathrm{P}$ and $\mathrm{KF}$ ) was observed for FC isolated from tertiary effluent disinfected by chlorine (20\%) in comparison to $5 \%$ of FC isolated from tertiary effluent disinfected by UV and 2\% FC isolated from secondary effluent.

For MDR Fecal coliform resistant to 5 antibiotics (P, CT, KF, F and TE) the highest level (24\%) was recorded for isolates from tertiary effluent disinfected by 
UV irradiation, as compared to $11 \%$ and $13 \%$ of FC isolates from tertiary effluent disinfected by chlorine and secondary effluent, respectively. MDR for 6 antibiotics (P, CT, KF, F, TE and AMP) was recorded for $13 \%, 9 \%$ and $7 \%$ of FC isolated from tertiary effluent disinfected by UV irradiation, secondary effluent and tertiary effluent disinfected by chlorine, respectively. It is worth noting that low percentage (up to 3\%) of FC isolates were MDR to even 7 antibiotics (P, CT, KF, F, TE, AMP and CN). Although, most FC released to the environment either for water reuse in irrigation or discharged into surface water bodies are not pathogenic, the high level of MDR detected in the treated effluents may introduce a high risk of spreading AR to environmentally transmitted pathogenic bacteria. MDR fecal coliform may be the source of horizontal transfer of antibiotic resistant genes. Our results show that disinfection procedures can result in differences in resistance patterns of FC to antibiotics. Huang et al. (2011) demonstrated that the inactivation of tetracycline-resistant $E$. coli was found significantly lower than that of antibiotic-sensitive E. coli at high chlorine doses [16]. However, opposite results were observed for ampicillin- and trimethoprim-resistant $E$. coli [17]. These authors suggested that chlorination does not select for ampicillinand trimethoprim-resistant $E$. coli through water treatment processes [17].

\subsection{Occurrence of Antibiotic Resistant Genes (ARG) of MDR Fecal Coliform}

Fecal coliform isolates found resistant to tetracycline and ampicillin using disk diffusion method were selected for the detection of genes associated with antimicrobial resistance using PCR. MDR fecal coliform isolates from secondary effluent $(n=25)$ and tertiary effluent treated either by chlorine $(n=25)$ or UV ( $n$ $=25$ ) were screened for the presence of the following antimicrobial resistance genes: tetracycline (tet $\mathrm{A}$ and tet $\mathrm{B})$ and $\beta$-lactamases $\left(\mathrm{ampC}\right.$ and $\left.\mathrm{bla}_{\mathrm{SHV}}\right)$. The highest prevalence $(100 \%)$ was observed for ampC gene in MDR isolated from secondary effluent and tertiary effluent disinfected by UV, whereas ampC gene was detected in only $50 \%$ of FC isolates from tertiary effluent disinfected by chlorine (Table 2). The gene bla $_{\mathrm{SHV}}$ was more frequently detected in MDR fecal coliform isolates from tertiary effluent disinfected by UV (83\%) than secondary and tertiary effluent disinfected by chlorine ( $28 \%$ and $10 \%)$, respectively. The MDR fecal coliform isolates were analyzed for the presence of two efflux pump encoding tetracycline resistance genes tet(A) and tet(B). The tet( $\mathrm{A})$ gene was found to be more prevalent in tertiary effluent disinfected by UV (52\%) than in MDR isolates from secondary effluents (44\%) and MDR isolates from tertiary effluent disinfected by chlorine (25\%), In comparison, tet(B) was found more frequently in MDR fecal coliform isolates from secondary effluent (88\%) and in MDR fecal coliform from tertiary effluents disinfected by UV (74\%) than in MDR isolates from tertiary effluents disinfected by chlorine (5\%) (Table 2). Previous study by Munir et al., 2001 found out that disinfection by chlorination and UV radiation did not significantly reduce ARGs and ARB and no difference was 
observed between the disinfection processes [18]. On the other hand, the application of sequential UV disinfection followed by chlorination significantly reduced the ARGs and had synergistic effects compared to single disinfectant use [19]. Moreover, Öncü et al. (2011) found out that the sensitivity to the antibiotics amoxicillin, ciprofloxacin and sulfamethoxazole was not altered in chlorine resistant E. coli [20]. Our results, although limited number of analyzed colonies, suggest that disinfection process may select for antibiotic resistant fecal coliform.

\subsection{Prevalence of Antibiotic Resistant Heterotrophic Bacteria (ARHTB) in Wastewater Effluents and Receiving Surface Water}

The prevalence of ARHTB in wastewater effluent and receiving surface waters was tested using ampicillin, tetracycline and chloramphenicol (Figure 2). The concentration of HTB resistant to ampicillin was the highest in the Yarkon outfall samples (up to $6 \times 10^{5} \mathrm{cfu} / 100 \mathrm{ml}$ ). The concentration of ampicillin resistant HTB in secondary effluent, tertiary effluent, wastewater irrigation reservoir and the Yarkon stream was lower than that recorded for the outfall, but was in the same order of magnitude. The concentration of ampicillin resistant HTB in the low impacted seawater was very low $(90 \mathrm{cfu} / 100 \mathrm{ml})$. The correlation between FC concentration and the level of HTB resistant to ampicillin was significant $(\mathrm{R}=$ $0.93, \mathrm{P}<0.05)$.

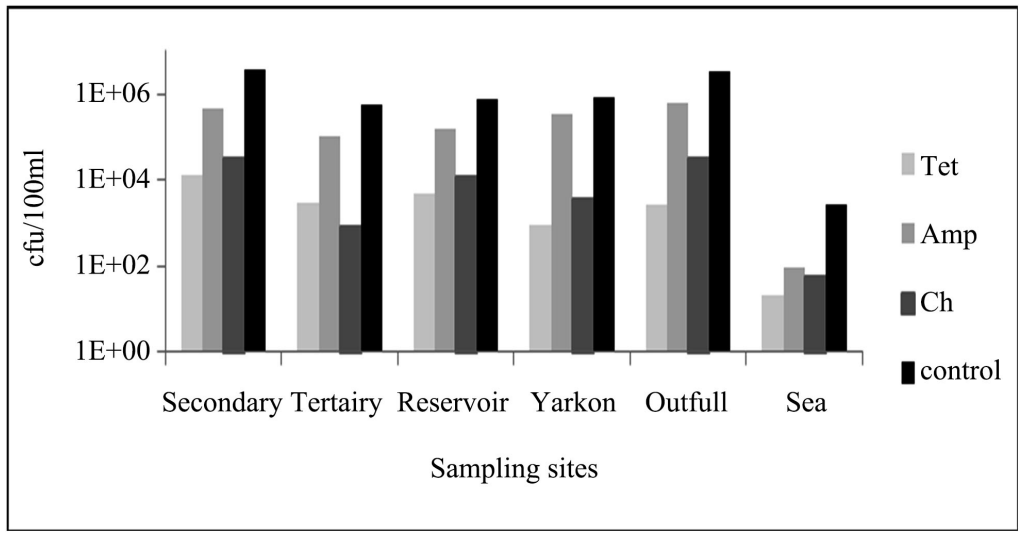

Figure 2. Concentration of heterotrophic bacteria resistant to ampicillin (A), tetracycline (B) and chloramphenicol (C) in wastewater effluents and receiving surface waters.

Table 2. Prevalence of antibiotic resistant genes (ARG) of MDR fecal coliform.

\begin{tabular}{|c|c|c|c|}
\hline \multirow{2}{*}{$\begin{array}{l}\text { Antibiotic resistant } \\
\text { gene }\end{array}$} & \multicolumn{3}{|c|}{ Prevalence (\%) of ARG in } \\
\hline & $\begin{array}{l}\text { Secondary effluent } \\
(\mathrm{n}=50)\end{array}$ & $\begin{array}{l}\text { Tertiary effluent UV } \\
\qquad(\mathrm{n}=25)\end{array}$ & $\begin{array}{l}\text { Tertiary effluent Chlorine } \\
\qquad(\mathrm{n}=25)\end{array}$ \\
\hline tet $\mathrm{A}$ & $44 \%$ & $52 \%$ & $25 \%$ \\
\hline tet $\mathrm{b}$ & $88 \%$ & $74 \%$ & $5 \%$ \\
\hline ampC & $100 \%$ & $100 \%$ & $50 \%$ \\
\hline Bla SHV & $28 \%$ & $83 \%$ & $10 \%$ \\
\hline
\end{tabular}


The highest concentration of tetracycline resistant HTB was observed in secondary effluent samples $\left(1 \times 10^{4} \mathrm{cfu} / 100 \mathrm{ml}\right)$, followed by samples from reservoir, tertiary effluent and Yarkon outfall. While the lowest concentration of HTB resistant to tetracycline in the receiving surface waters was recorded in the Yarkon stream $\left(9 \times 10^{2} \mathrm{cfu} / 100 \mathrm{ml}\right)$. The low impacted seawater contained $20 \mathrm{cfu} / 100 \mathrm{ml}$ tetracycline resistant HTB. Weak correlation was recorded between FC concentration and the concentration of $\mathrm{HTB}$ resistant to tetracycline $(\mathrm{R}=0.37, \mathrm{P}<$ 0.05).

Similar concentration of HTB resistant to chloramphenicol was observed in secondary effluent and stream outfall $\left(10^{4} \mathrm{cfu} / 100 \mathrm{ml}\right)$. Only $60 \mathrm{cfu} / 100 \mathrm{ml}$ HTB resistant to chloramphenicol were detected in the low impacted seawater. Significant correlation was recorded between FC concentration and the concentration of HTB resistant to chloramphenicol $(\mathrm{R}=0.95, \mathrm{P}<0.05)$.

In general, the concentration of HTB resistant to ampicillin in the various water sources was highest followed by HTB resistant to chloramphenicol and lowest was recorded for tetracycline. The level of FC detected in the stream outfall samples suggest that additional wastewater contamination may be discharged close to the sampling location.

\subsection{Prevalence of ARG in Wastewater Effluents and Receiving Surface Waters}

Samples of wastewater effluent and receiving surface waters were screened for the presence of 8 ARGs which included; tetracycline resistance genes (tet A, tetB, tetC), $\beta$-lactams resistance genes (ampC, bla ${ }_{\mathrm{SHV}}$, blapse1), and chloramphenicol resistance genes (Flor, and Cat).

The most prevalent detected gene was $\operatorname{ampC}$, which was detected in all samples (100\%), except in the low impacted seawater samples (29\%) (Table 3). In comparison, $57 \%$ of samples from secondary, tertiary effluents and the stream outfall harbored bla $\mathrm{SHV}_{\mathrm{SH}}$ gene, while bla $\mathrm{SHV}_{\mathrm{SH}}$ gene was detected in only $29 \%$ of samples from the irrigation reservoir and Yarkon stream the bla $\mathrm{SHV}_{\mathrm{SH}}$ gene was detected. The lowest level of bla $\mathrm{SHV}_{\mathrm{SH}}$ gene $(14 \%)$ was detected in the low impacted seawater samples. The ARG blapse1 was highly prevalent in samples of effluents, reservoir, and Yarkon Stream (100\%) and found at lower prevalence in low impacted seawater (43\%).

The prevalence of three efflux pump genes (tet $\mathrm{A}$, tetB, and tetC) encodes resistance against tetracycline were examined in wastewater effluents and receiving water bodies (Table 3 ). Genes tetA and tetC were highly prevalent (100\%) in all tested samples, whereas tetA was completely absent and tetC was detected in $29 \%$ samples from low impact sea samples. In comparison, tetB was prevalent in all secondary effluent samples (100\%), followed by samples from the Yarkon outfall and the irrigation reservoir (57\%). In tertiary effluents and outfall samples tetB was present in only $29 \%$ of the samples. Gene tetB was detected in only $14 \%$ of the analyzed low impact seawater samples. 
Table 3. Prevalence of ARG in wastewater effluents and receiving surface water.

\begin{tabular}{|c|c|c|c|c|c|c|c|}
\hline $\begin{array}{l}\text { Antibiotic } \\
\text { resistant gene to }\end{array}$ & gene & SW & $\mathrm{TE}$ & Res & Stream & Outfall & $\begin{array}{l}\text { Low } \\
\text { impact }\end{array}$ \\
\hline \multirow[t]{3}{*}{ Tetracycline } & tet $\mathrm{A}$ & $100 \%$ & $100 \%$ & $100 \%$ & $100 \%$ & $100 \%$ & $0 \%$ \\
\hline & tet $\mathrm{B}$ & $100 \%$ & $29 \%$ & $57 \%$ & $29 \%$ & $57 \%$ & $14 \%$ \\
\hline & tet $\mathrm{C}$ & $100 \%$ & $100 \%$ & $100 \%$ & $100 \%$ & $100 \%$ & $29 \%$ \\
\hline \multirow[t]{3}{*}{$\beta$-lactams } & ampC & $100 \%$ & $100 \%$ & $100 \%$ & $100 \%$ & $100 \%$ & $86 \%$ \\
\hline & $\mathrm{bla}_{\mathrm{SHV}}$ & $57 \%$ & $57 \%$ & $29 \%$ & $29 \%$ & $57 \%$ & $14 \%$ \\
\hline & blapsel & $100 \%$ & $100 \%$ & $100 \%$ & $100 \%$ & $86 \%$ & $43 \%$ \\
\hline \multirow[t]{2}{*}{ chloramphenicol } & Flor & $100 \%$ & $71 \%$ & $100 \%$ & $86 \%$ & $100 \%$ & $0 \%$ \\
\hline & Cat & $100 \%$ & $100 \%$ & $100 \%$ & $86 \%$ & $100 \%$ & $29 \%$ \\
\hline
\end{tabular}

Two chloramphenicol resistance genes (Cat and floR) were detected in all $(100 \%)$ samples from secondary effluents, reservoir, and the outfall, while in samples from tertiary effluents, cat gene was highly prevalent (100\%) and floR gene was observed in $71 \%$. In samples of the Yarkon stream, the frequencies of both genes displayed the same frequency (86\%). Cat gene was detected in $29 \%$ of samples from the low impacted seawater, whereas, floR gene was not detected in low impact seawater.

The results of our study support the conclusions drawn by Luczkiewicz et al., 2010 , who reported that treated wastewater contained up to $90 \%$ antibiotic resistant $E$. coli. Furthermore, the researchers observed a positive selection of isolates with antimicrobial patterns during the wastewater treatment [21]. The results indicate that wastewater treatment plants can be a substantial source for antibiotic resistance bacteria and genes in the receiving aquatic environments. Special concern should be paid to the isolates resistant to 3 or more chemical classes of antibiotics.

Urase and Sato (2016) studied the antimicrobial resistance to fluoroquinolones and third-generation cephalosporins in the Tama river watershed [22]. High occurrence of the multiple resistant bacteria to different classes of newer antimicrobials was reported. The results presented are in agreement with those reported previously, which have shown that the prevalence of ARB in receiving surface water is equal or not lower than their prevalence in treated wastewater effluents [22] [23] [24]. These observations suggest that wastewater treatment plants are the major source of ARB and ARG, therefore suitable measures should be applied to reduce their discharge to the environment and receiving water bodies.

This study highlights the importance of wastewater treatment plants in the transmission of ARB and ARG to the environment and especially to receiving streams, rivers and marine waters. The persistence of ARB and ARG in marine waters may enhance the horizontal transmission of ARG to pathogenic bacteria. The results indicate that the Mediterranean coastal waters may be contaminated by $A R B$ and $A R G$ which introduce a serious public health problem for bathers 
and seafood harvested from contaminated regions. Improved wastewater treatment technologies should be applied to reduce the levels of ARG and ARB released to the environment.

\section{Conclusions}

1) High occurrence was observed for MDR fecal coliform in wastewater treated effluents.

2) High prevalence of ARG in fecal coliform isolates for $\beta$-lactam and tetracycline in treated effluents was recorded.

3) Treatment of effluents by chlorination or UV irradiation may select for specific antibiotic resistance.

4) Wastewater effluents are the source of ARB in surface waters receiving the effluents. Therefore, ARB and ARGs in water bodies can serve as the source of ARGs for pathogenic bacteria.

\section{Conflicts of Interest}

The authors declare no conflicts of interest regarding the publication of this paper.

\section{References}

[1] Rizzo, L., Manaia, C., Merlin, C., Schwartz, T., Dagot, C., Ploy, M.C., Michael, I. and Fatta-Kassinos, D. (2013) Urban Wastewater Treatment Plants as Hotspots for Antibiotic Resistant Bacteria and Genes Spread into the Environment: A Review. Science of the Total Environment, 447, 345-360. https://doi.org/10.1016/j.scitotenv.2013.01.032

[2] Michael, I., Rizzo. L., McArdell, C.S., Manaia, C.M., Merlin, C., Schwartz, T., Dagot, C. and Fatta-Kassinos D. (2013) Urban Wastewater Treatment Plants as Hotspots for the Release of Antibiotics in the Environment: A Review. Water Research, 47, 957-995. https://doi.org/10.1016/j.watres.2012.11.027

[3] Czekalski, N., Diez, E.G. and Burgmann, H. (2014) Wastewater as a Point Source of Antibiotic-Resistance Genes in the Sediment of a Freshwater Lake. Multidisciplinary Journal of Microbial Ecology, 8, 1381-1390. https://doi.org/10.1038/ismej.2014.8

[4] Stoll, C., Sidhu, J.P., Tiehm, A. and Toze, S. (2012) Prevalence of Clinically Relevant Antibiotic Resistance Genes in Surface Water Samples Collected from Germany and Australia. Environmental Science \& Technology, 46, 9716-9726. https://doi.org/10.1021/es302020s

[5] Li, X.-D., Watanabe, N., Xiao, C.-L., Harter, T., McCowan, B., Liu, Y.-J. and Atwill, E.R. (2014) Antibiotic-Resistant E. coli in Surface Water and Groundwater in Dairy Operations in Northern California. Environmental Monitoring and Assessment, 182, 1253-1260. https://doi.org/10.1007/s10661-013-3454-2

[6] Xi, C.-W., Zhang, Y.-L., Marrs, C.F., Ye, W., Simon, C., Foxman, B. and Nriagu, J. (2009) Prevalence of Antibiotic Resistance in Drinking Water Treatment and Distribution Systems. Applied and Environmental Microbiology, 75, 5714-5718. https://doi.org/10.1128/AEM.00382-09

[7] Rosas, I., Salinas, E., Martínez, L., Cruz-Córdova, A., González-Pedrajo, B., Espinosa, 
N. and Amábile-Cuevas, C.F. (2015) Characterization of Escherichia coli Isolates from Urban Lake Receiving Water from Wastewater Treatment Plant in Mexico City: Fecal Pollution and Antibiotic Resistance. Current Microbiology, 71, 490-495. https://doi.org/10.1007/s00284-015-0877-8

[8] Frost, L.S.R., Leplae, A., Summers, O. and Toussaint, A. (2005) Mobile Genetic Elements: The Agents of Open Source Evolution. Nature Reviews Microbiology, 3, 722-732. https://doi.org/10.1038/nrmicro1235

[9] Moore, P.C. and Lindsay, J. (2001) Genetic Variation among Hospital Isolates of Methicillin-Sensitive Staphylococcus aureus. Evidence for Horizontal Transfer of Virulence Genes. Journal of Clinical Microbiology, 39, 2760-2767. https://doi.org/10.1128/JCM.39.8.2760-2767.2001

[10] Parsley, L.C., Consuegra, E.J., Kakirde, K.S., Land, A.M., Harper Jr., W.F. and Liles, M.R. (2010) Identification of Diverse Antimicrobial Resistance Determinants Carried on Bacterial, Plasmid, or Viral Metagenomes from an Activated Sludge Microbial Assemblage. Applied and Environmental Microbiology, 76, 3753-3757. https://doi.org/10.1128/AEM.03080-09

[11] World Health Organization (WHO) (2014) Antimicrobial Resistance: Global Report on Surveillance.

[12] Alekshun, M.N. and Levy, S.B. (2007) Molecular Mechanisms of Antibacterial Multidrug Resistance. Cell, 128, 1037-1050. https://doi.org/10.1016/j.cell.2007.03.004

[13] APHA, AWWA and WEF (2015) Standard Methods for the Examination of Water and Wastewater.

[14] CLSI (Clinical and Laboratory Standards Institute) (2006) Performance Standards for Antimicrobial Susceptibility Testing. Sixteenth Informational Supplement.

[15] James, C.E., Mahendran, K.R., Molitor, A., Bolla, J.-M., Bessonov, A.N., Winterhalter, M. and Pagès, J.-M. (2009) How Beta-Lactam Antibiotics Enter Bacteria: A Dialogue with the Porins. PLoS ONE, 4, e5453. https://doi.org/10.1371/journal.pone.0005453

[16] Huang, J.-J., Hu, H.-Y., Tang, F., Li, Y., Lu, S.-Q. and Lu, Y. (2011) Inactivation and Reactivation of Antibiotic-Resistant Bacteria by Chlorination in Secondary Effluents of a Municipal Wastewater Treatment Plant. Water Research, 45, 2775-2781. https://doi.org/10.1016/j.watres.2011.02.026

[17] Templeton, M.R., Oddy, F., Leung, W. and Rogers, M. (2009) Chlorine and UV Disinfection of Ampicillin-Resistant and Trimethoprim-Resistant Escherichia coli. Canadian Journal of Civil Engineering, 36, 889-894. https://doi.org/10.1139/L09-040

[18] Munir, M., Wong, K. and Xagoraraki, I. (2001) Release of Antibiotic Resistant Bacteria and Genes in the Effluent and Biosolids of Five Wastewater Utilities in Michigan. Water Research, 45, 681-693. https://doi.org/10.1016/j.watres.2010.08.033

[19] Destiani, R. and Templeton, M.R. (2019) Chlorination and Ultraviolet Disinfection of Antibiotic-Resistant Bacteria and Antibiotic Resistance Genes in Drinking Water. AIMS Environmental Science, 6, 222-241. https://doi.org/10.3934/environsci.2019.3.222

[20] Öncü, N.B., Menceloğlu, Y.Z. and Balcıoğlu, I.A. (2011) Comparison of the Effectiveness of Chlorine, Ozone, and Photocatalytic Disinfection in Reducing the Risk of Antibiotic Resistance Pollution. Journal of Advanced Oxidation Technologies, 14, 196-203. https://doi.org/10.1515/jaots-2011-0203

[21] Łuczkiewicz, A., Jankowska, K., Fudala-Książek, S. and Olańczuk-Neyman, K. (2010) 
Antimicrobial Resistance of Fecal Indicators in Municipal Wastewater Treatment Plant. Water Research, 44, 5089-5097.

https://doi.org/10.1016/j.watres.2010.08.007

[22] Urase, T. and Sato, T. (2016) Quantitative Monitoring of Resistance in Escherichia coli to Clinically Important Antimicrobials in an Urban Watershed. Journal of Water and Environment Technology, 14, 341-349.

[23] Iwane, T., Urase, T. and Yamamoto, K. (2001) Possible Impact of Treated Wastewater Discharge on Incidence of Antibiotic Resistant Bacteria in River Water. Water Science \& Technology, 43, 91-99. https://doi.org/10.2166/wst.2001.0077

[24] Ham, Y.S., Kobori, H., Kang, J.-H., Matsuzaki, T., Iino, M. and Nomura, H. (2012) Distribution of Antibiotic Resistance in Urban Watershed in Japan. Environmental Pollution, 162, 98-103. https://doi.org/10.1016/j.envpol.2011.11.002 